\title{
Non-philosophical Christ-poetics beyond the mystical turn in conversation with continental philosophy of religion

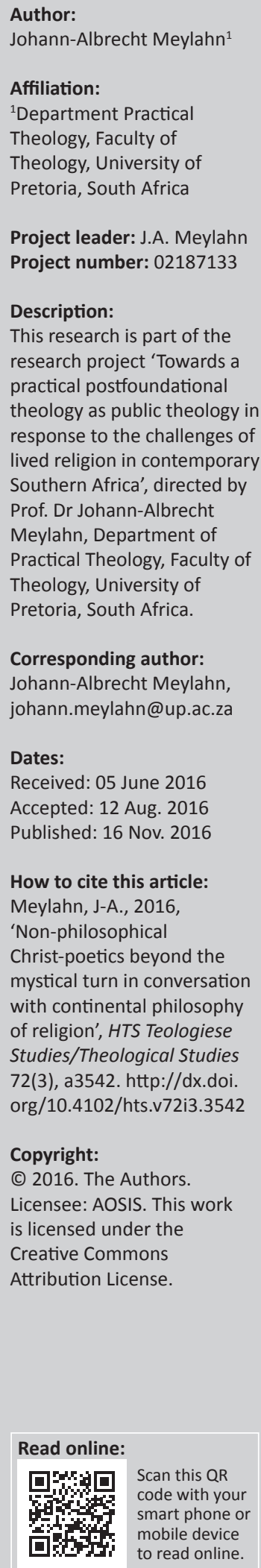

The religious turn in continental philosophy has opened the door for postmetaphysical mystical theology. Postmetaphysical mystical theology seeks to understand the non-relation relation of language (text) to the Other. Yet, this non-relation relation to the Other, who is every other, can also be interpreted differently to the mystical understanding. For example, Žižek argues that the Other, which is often experienced as the uncanny, the unpredictable and the contingent (lived spirituality), is not necessarily the result of some mystical unknowable Otherness but is a consequence of the way the subject's own activity is inscribed into reality. These experiences of lived spirituality or experiences of Otherness can, rather than being interpreted as an in-breaking of the mystical Other, be interpreted otherwise, as a grammatological consequence of the inability and impossibility of language (Lacan). Therefore, in this article, Žižek's thoughts function as a bridge to bring this mystical turn back into critical conversation with continental philosophy and particularly with the thoughts of Derrida, Laruelle and Stiegler. The contemporary mystical turn in theology rediscovers something of this non-religious religion. Derrida's thoughts are in close proximity to negative theology and yet there is an important difference. This difference will be explored and further developed towards Laruelle's non-philosophy, which does not translate into a non-religion religion or postmetaphysical metaphysics but remains a non-philosophy or maybe a science of Christ. This article will conclude with a tentative exploration of a postmetaphysical Christ-poetics beyond the mystical turn.

\section{Returning to God after God}

The so-called religious turn in continental philosophy of religion has opened the door for a mystical turn towards what can be termed a postmetaphysical mystical theology, for example, Richard Kearney's (2001) God who may be, or Kearney's (2010) Anatheism, or John Caputo's (2006) The weakness of God, or Caputo's (2013) The insistence of God: A theology of perhaps or Calvin Schrag's (2002) God as otherwise than being, to mention only a few recent publications.

What I mean by postmetaphysical mystical theology is a way to understand the non-relation relation of language or thought (text) to the Other. It is an attempt to understand (or write about), conceptualise and put to text Being or the Other or Being-as-Multiple. It is an attempt to come to terms (come to language), and talk about 'that' which is beyond the grasp (Begriff) of language, the unnameable, the uncanny or the wholly Other or the unconditional. To come to terms (language) with what is beyond terms (language); the uncanny, mysterious; or to come to terms (make calculable) with that which is incalculable. This incalculable has to be emplotted, in reference to Ricouer's understanding of emplotment (Ricouer 1984:31ff), into a calculable or meaningful thought (text). Derrida ${ }^{1}$ describes the relationship between the calculable and the incalculable or the relationship between what makes sense, the calculable, and what comes across as strange, other or incalculable, when he argues that it is the self (same) that produces this event of the incalculable.

It is this incalculable, beyond language, that is, if such a thing exists, which is the cause or inspiration for various texts and novels (Joyce, Proust, Woolf) as discussed by Richard Kearney (2010) in his book, Anatheism. Kearney asks the question if it is possible to return to God after leaving God?2 That depends on the kind of God one is attempting to return to, but in the philosophical time-space at the closure of metaphysics, it seems impossible to return to a mighty

1.'A performative produces an event only by securing for itself, in the first person singular or plural, in the present, and with the guarantee offered by conventions or legitimated fictions, the power that an ipseity gives itself to produce the event of which it speaks, the event that it neutralises forthwith insofar as it appropriates for itself a calculable mastery over it' (Derrida 2003:43).

2.'Was it possible, I asked after a meeting with Jean Vanier in Compiègne in 1978, to return to God after leaving God? And if so, what kind of God were we talking about?' (Kearney 2010:loc 118 of 6156). 
monarch or an omnipotent causality. Yet, with the rise in various forms of fundamentalism, even this seems possible as there is a clear return to a mighty metaphysical monarch, a clear and unquestionable foundation or certainty.

The closure of metaphysics or the end of metaphysics seems to have come together with a resurrection of the gods, who are now at war with each other. These various gods are not only engaged in religious wars with each other but are also at war with those who militantly argue that there is no God (atheism). In this war between theisms versus atheisms, Kearney offers an anatheist space 'where the free decision to believe or not believe is not just tolerated but cherished' (Kearney 2010:127 or 6156).

Kearney's anatheism seems to be a practical solution in this time of religious wars, as it is a space for all those who are not so certain about either theism or atheism. It is a space for all those who experience instants of 'deep disorientation, doubt, or dread, when we are no longer sure exactly who we are or where we are going' (Kearney 2010:5). Kearney's anatheism is, as he argues, both before and after atheism. ${ }^{3}$ In a sense, it is seen as a deeper discovery of faith after an atheistic moment of doubt. ${ }^{4}$

There is a need to reflect and think about the experience of the uncanny, the unexplainable, the incalculable and unconditional, that which questions certainties: the Other. This Other can be experienced in the lived experiences of the uncanny, experiences of contingency, the experiences or frustration that life cannot be controlled nor foretold, namely the experiences of the Geschichtlichkeit of life. These experiences bring back into daily life experiences of the Other, the mysterious and the sublime (see also Meylahn 2015). To come to terms, to language, with this mysterious Other, there is not only a return to religion but also a return to magic and the supernatural. This return to magic and supernatural finds expression in various movies and novels in contemporary popular culture, which have the supernatural as their theme (Harry Potter, and all the vampire movies and books amongst others).

The reason that there is an openness to welcome a return to religion or a return to supernatural is the human experience of the uncanny, inexplicable Other. It is the experience that certain events, experiences and feelings cannot be emplotted into a coherent narrative (see Ricoeur 1984:31ff). In response to these lived spiritual experiences of the Other, there is the need for alternative narrative that has the ability to make sense and give meaning, give expression to and offer understanding of that which was experienced as being

3.'Anatheism presupposes this a-theistic moment as antidote to dogmatic theism True faith, as Dostoyevsky puts it, "bursts forth from the crucible of doubt" (Kearney 2010:5). 'It operates before as well as after the division between theism and atheism, and it makes both possible. Anatheism, in short, is an invitation to revisit what might be termed a primary scene of religion: the encounter with the radical Stranger who we choose, or don't choose, to call God' (Kearney 2010:7).

4.'Almost all the great mystics and sages attested to a moment of agnostic abandonment as crucial transition to deeper faith' (Kearney 2010:8). 'Anatheism acknowledges the emancipator force of critical atheism as an integral part of theism, understood as a second faith beyond faith' (Kearney 2010:16). beyond understanding and calculation. Those narratives that are created to come to terms with the incalculable could probably be understood as sacred stories (Crites 1989:69), which are attempts to make sense of and give ultimate meaning to these experiences. Van den Hoogen (2013) argues that these sacred stories are a form of becoming conscious of lived spirituality - to become conscious of that which was beyond understanding by emplotting the incalculable into a calculable narrative (sacred story). These sacred stories are then various forms of religion. Religion is understood very broadly as attempts to give ultimate meaning and sense to these lived spiritual experiences of the unexplainable (see also Meylahn 2015). Is anatheism one more sacred story that seeks to emplot the lived experience of the unconditional, the Other, Stranger?

It is an experience of that which transcends the grip (begreifen) of language and it can be grouped, as Laruelle does, into three basic ideas: Being (the ontology of the Ancients), or the Other (contemporary deconstructions of ontology) or Beingwithout-One (ontology of Being-as-Multiple) (Laruelle 2013:Kindle 792-794).

The question that fascinates me is: Can a source or a cause be named for these experiences? Is there a source, an origin or a 'cause' for these experiences? These are typical metaphysical questions. Is it something or someone, is it the stranger ${ }^{5}$ that comes knocking at the door seeking hospitality? Is it the visitation of the angels to Abraham or the angel's visit to Mary? Is it the experience of the multiple? Is it that which has been forgotten (Seinsvergessenheit)? Or perhaps, this lived spirituality, that which challenges the enclosure of metaphysics, is a form of dis-enclosure as Jean-Luc Nancy argues (2008)? It is an opening of the closure of metaphysics. The question that needs to be asked is, who or what opens the enclosure of metaphysics, who or what knocks, as stranger, on the closure of metaphysics (Derrida 1997:4) at the verwindung (wounding) of metaphysics (Heidegger 2003:84)? Is it a who or a what, a kind of being, perhaps transcendent, or maybe the transcendent, or maybe a transcendental that knocks? Derrida, in The World of the enlightenment to come, argues that what is called for is a:

rationality that takes account of the incalculable so as to give an account of it, there where this appears impossible, so as to account for or reckon with it, that is to say, with the event of what or who comes. (Derrida 2003:50)

Is it perhaps a resurrected God who opens the enclosure of metaphysics? Or is it the last God who signals (winkt), or is it maybe the signal of a last God. ${ }^{6}$ Or is it perhaps, perhaps as Derrida argues in Politics of Friendship? ${ }^{7}$ Who or what would

5. The stranger, in short, is the uninvited one with nowhere to lay its head unless we act as "hosts" and provide a dwelling' (Kearney 2010:21). 'You either welcome or refuse the stranger. Monotheism is the history of this wager' (Kearney 2010:22).

6. That the signal "a god" or again, the "signal of a God" - might be necessary or not here remains once again undecided. That will perhaps remain undecidable - or not. But, for the moment, it is at least beyond all doubt that a signal, whatever it may be, addresses us from the site of our atheist reason' (Nancy 2008:28).

7.'What is going to come, perhaps, is not only this or that; it is at last the thought of the perhaps, the perhaps itself' (Derrida 2005:29). 
this perhaps be, this un-decidability? An un-decidability that is very close to Kearney's anatheism. ${ }^{8}$ Who or what is this stranger who comes to disrupt or to interrupt the tranquillity of the enclosure, so as to bring about doubt, disorientation or alternatively experiences of the sublime? Who is the arrivant, Derrida asks? He responds and says: 'The arrivant will arrive perhaps, for one must never be sure when it comes to arrivance; but the arrivant could also be the perhaps itself, the unheard-of, totally new experience of the perhaps' (Derrida 2005:29). The difference of the arrivant (stranger) as well as the deferral of the arrival is Derrida's interpretation of différance (Derrida 1982:7, n. 7). Is différance, the perhaps, a stranger that knocks at the door of the enclosure seeking hospitality, and in seeking hospitality becomes the host and thereby dis-enclosures the enclosure? Would this not be a kind of metaphysical ethics as argued by Levinas (1969:52)? I believe it would, as the Other/Stranger would fulfil the position of the transcendent. Yet, Derrida does not argue that différance is a stranger, but différance is inscribed into language itself; in his later work, for example, Politics of Friendship (2005), he will make use of the term autoimmunity. ${ }^{9}$ In other words, it is not something from outside that knocks, but it is something internal to language, language understood as pharmakon or supplement, therefore as différance. In Derrida's work, there are numerous figures of the unconditional, but none of these tends towards the mystical or mysterious, for example, the figures that Derrida does refer to are: the unconditional hospitality, gift, justice or forgiveness. ${ }^{10}$ One could perhaps speak of a quasi-transcendental (see Horner 2001:70-71) rather than any form of a transcendent.

Derrida argues that one should not seek to think the One and the Other, but to think the calculable and incalculable together ${ }^{11}$ and that is the challenge of reason still to come. ${ }^{12}$

Perhaps, and one would be left with a mystical spirituality of welcome offered to strangers, an infinite responsibility to the Other. Perhaps, it is not the stranger who knocks and thereby interrupting and disrupting the enclosure, or even calling the enclosure into being, but the finitude 8.... anatheism differs from dogmatic atheism in that it resists absolutist positions
against the divine, just as it differs from the absolutist positions of dogmatic theism for the divine' (Kearney 2010:15)

9. He argues, 'If an event worthy of this name is to arrive or happen, it must, beyond all mastery, affect a passivity. It must touch an exposed vulnerability, one without absolute immunity, without indemnity; it must touch this vulnerability in its finitude and in a non-horisontal fashion, there where it is not yet or is already no longer possible to face or face up to the unforeseeability of the other. In this regard, autoimmunity is not an absolute ill or evil, it enables an exposure to the other, to what and to who comes which means that it must remain incalculable. Without autono longer wait, await, or expect, no longer expect one another, or expect any no longer wait, await, or expect, no longer
event' (Derrida 2003:43 emphasis mine).

10.'In the open series of these examples, we have to think together two figures of rationality that, on either side of a limit, at once call for and exceed one another. The incalculable unconditionality of hospitality, of the gift or of forgiveness, exceeds the calculation of conditions, just as justice exceeds law, the juridical, and the political' (Derrida 2003:40-41).

11.The challenge is to think together both this 'heterogeneity and this inseparability is to recognise, and so bear witness to, an auto-delimitation that divides reason and that is not without relation to a certain auto-immunity' (Derrida 2003:41).

12.'This responsibility of reason, this experience that consists in keeping within reason [à raison garder], in being responsible for a reason of which we are the heirs, could be situated with only the greatest of difficulty. Indeed I would situate it precisely within this greatest of difficulties, within the auto-immunitary aporia of this within this greatest of difficulties, within the auto-immunitary aporia of this
impossible transaction between the conditional and the unconditional, calculation and the incalculable' (Derrida 2003:41-42). (death or poison - pharmakon ${ }^{13}$ ) or lack in language itself, as Žižek argues: 'the way the subject's own activity is inscribed into reality' (Žižek 2009:244). Derrida argued that the challenge is to think this within reason (Derrida 2003:41) and not to wander beyond the confines of reason into the mystical or supernatural. Who can decide between these two perhapses? Or maybe these multiple possibilities of perhaps are a consequence of the grammatology of language, how human activity is inscribed into reality. It is something that happens in-reason and not a matter of the unreasonable.

\section{Perhaps not the stranger or perhaps the stranger or perhaps, perhaps}

Is it the stranger, the mysterious, the sublime or uncanny who or what disrupts the enclosure, opening the enclosure to dis-enclosure, or is it différance inscribed into the enclosure that disrupts and interrupts itself? Perhaps, one cannot decide between différance that is and the stranger that comes? Or perhaps, there is a stranger, mysterious, uncanny that comes because différance is and therefore something that can be 'contained' immanent to reason or language. There is no 'God's-eye-view' to decide on all these un-decidables. There is only a vision-in-One, ${ }^{14}$ where the stranger is not the one who comes, but the one who is, the immanent stranger (Laruelle 2014:57). Laruelle contrasts his non-philosophy with deconstruction by arguing that deconstruction

consists in establishing play 'between' the parts, in making them move in relation to each other. This relation between parts is absolute because of the supplement of an absolute Other. Deconstruction insists in undoing the enclosure or the foreclosure of a system without breaking it, in unbinding the organisation of the set, in weakening the disposition [systase] of the system (Heidegger), in making disseminated strangeness appear. (Laruelle 2014:57)

Laruelle's non-philosophy on the other hand:

does not emphasise otherness or differences; it does not compound them through différance, and does not content itself with establishing play while conserving the deconstructionist's ex machina authority (which amounts to the same thing as enclosure). It does not add to nor subtract from the immanent deconstruction of the thing (of texts); rather, it substitutes unilateralism for difference (différance), and it breaks the enclosure, at least for the Real ... Then there is a pure otherness that delimits, not in opposition to immanence (which has no limit), but a One-limitation that is opposed to the system as its possibilising impossibility. (Laruelle 2014:57)

13.See Derrida's chapter, Plato's Pharmacy (Derrida 1981:67ff) from his book Dissemination.

14.In order to find our feet within the scholastic and mystic tradition, we will distinguish between the transcendental One, proper to philosophy; the transcendent One, proper to historical and religious mysticism; and finally from these two "Ones" - and this is what will distinguish non-philosophy from philosophy and from philosophico-mystic mixtures - the simply real One, which is only immanent (to) itself, for which immanence is real essence or "substance" rather than relation or ownership. The One through immanence distinguishes itself rather than relation or ownersh. as much from the transcendent One as from the transcendental One: on the condition that it is radical immanence, without the smallest fragment of transcendence within it, of exteriority, of scission, of negativity, or of nothingness. We call this One-in-One rather than One-in-Being or as-Being; One which is real as One rather than as it is or would be; we can equally say "vision-in-One", and bette still, "seen-in-One"' (Laruelle, Francois (2013-05-09). Principles of Non-Philosophy (Kindle Locations 485-490). Bloomsbury Publishing. Kindle Edition). 
Laruelle wants to move away from the thinking of the unconditional as the condition of the conditional, the Other as the principle for the thinking of the same or the other way around, but argues that these are all philofictions. ${ }^{15}$

In this vision-in-One, there is perhaps a relationship with this perhaps, a relationship with an absolutely unknown future, where it is not known if it is the stranger or différance or something else, but an absolute future (Laruelle 2011) of only perhaps.

\section{The God after God or the wink of the last God has opened the door (dis-enclosure) to all sorts of mysteries and mysticisms}

Nancy (2008:104f) engages with the wink of Heidegger's last God. This last God that opens the door to all sorts of mysteries and mysticisms, but perhaps this door needs to be closed somewhat again. Or at least to gain some critical perspective (not a God's-eye-perspective) on what is twinkling (signalling) in the unknown abyss surrounding the enclosure, or rather to gain some kind of rationality to think, not what is incalculable or beyond, but to realise that the incalculable, as Derrida argues in the previous section, incalculable and calculable needs to thought together as part of the autoimmunity of language itself. It is not the abyss surrounding the enclosure, but rather the abyss that is in language itself. Or perhaps, one does not need to think about the abyss at all, as the abyss is just one more thought-path of philosophy that becomes material for non-philosophy.

The critical perspective will be offered by trying to understand the need for religion. Or in the words of Jean-Luc Nancy:

It is not a question of reviving religion, not even the one that Kant wanted to hold 'within the limits of reason alone'. It is, however, a question of opening mere reason up to the limitlessness that constitutes its truth. It is not a question of overcoming some deficiency in reason, but of liberating reason without reserve: once everything is accounted for, it is up to us to show what remains beyond these accounts. It is also not a question of repainting the skies, or of reconfiguring them: it is a question of opening up the earth - dark, hard, and lost in space. (Nancy 2008:1)

For Nancy, it is rather a question of knowing what the simple word human means ${ }^{16}$ (Nancy 2008:2). Humans are rational beings, by saying this I am not excluding other creations from rationality, but am rather focusing on reason, rationality and how human reason inscribes itself.

15.'Non-philosophy leads to a philo-fiction that consists not so much of disassembling an assumed given system in a spectral dimension, but which rather starts by presenting the system as given under the auspices of human Identity (an identity presenting the system as given under the auspices of human Identity (an identity that is unknown and foreign to the system), and describes what is deduced as 2014:61).

16.'Behind this word, behind what it says, behind what it hides - what it does not want to say, what it cannot or does not know how to say - stands the most want to say, what it cannot or does not know how
imperious demands of thought today' (Nancy 2008:2).
Instead of seeking God beyond the text, the suggestion is to seek God in the text - as the infinite desertification of language, which is Derrida's suggestion (Derrida 1995:55-56). Derrida's interpretation of God, as the infinite desertification of language, has some similarities with negative theology (see Derrida 1995, 2008; Meylahn 2013b:226ff, 2015). Yet, he takes great pains to show that although there is proximity between différance and the God of negative theology, there is also an important difference and therefore Derrida does not follow the mystical turn in theology as, for example, Kearney (2010) does. ${ }^{17}$ Différance is not another name for God.

Following Derrida and his close proximity and yet difference to negative theology, one can conclude that God is unknowable and therefore no conclusive statements can be made with regard to either theism or atheism. This sounds very similar to Kearney's Anatheism, and yet Kearney differentiates himself from Derrida (Kearney 2010:64). Kearney asks, 'does deconstructive "faith" not risk becoming so empty that it loses faith in the here and now altogether?' (Kearney 2010:64). Later he argues against Derrida, that Derrida might save the name God, but it does not entail a return to the Named. 'At best, it is an "endless waiting in the desert", a waiting for Godot who never comes' (Kearney 2010:65). Kearney rather argues for the mystery of the Other and develops an ethic of hospitality towards the stranger as a kind of postmetaphysical mystical theology. Thereby, he again places an ethical demand on the individual with knowledge of what is good and evil. The knowledge of the good is to offer welcome to strangers, to offer hospitality, love. A weak knowledge, or a way towards 'truth', is developed as he seeks to develop a theology of hospitality and love, thereby trying to get a vulnerable grip on Reality and on the elusive Other (see also Meylahn 2015). Derrida's atheism that can pass for theism, or Kearney's Anatheism, which keeps the question of theism and atheism in creative tension, argues the same, namely that no conclusive answer can be given with regard to the wholly Other who is every other, as Derrida (1995:76) says (tout autre est tout ature). This is the difference between Derrida and Kearney. Kearney still seeks to come to terms with the Other, while Derrida argues that it is just as true for every other, as every other is wholly other.

No conclusive statements can be made about God, but neither about Reality, and therefore all statements about theism or atheism are pure speculations, just as statements about Reality are speculations. Derrida tries to avoid a new dualism between speculative realism and speculative mysticism concerning the Other or Stranger. The best way to avoid these different speculations is to focus on what one does have, namely texts, which one can understand as the turn to literature, rather than the turn to religion. In Kearney's

\footnotetext{
17.'Mysticism is less a heresy or a liberation from religion than an instrument for the work of unveiling, within religion itself, a truth that would first be formulated in the wode which would then be able makes a nonreligious exegesis of religion possible. It also gives rise, in the historical relation of the West to itself, to a reintegration that eradicates the past without losing its meaning' (Kearney 2010:9).
} 
Anatheism, there is also a turn to literature, but towards the mystical stranger or Other in various literary works. He does this by identifying in three great novels of Western literature themes of Otherness. On the contrary, the turn to literature that I am referring to is the turn to text and nothing beyond text. To turn to what happens in texts, or in Žižek's words, to turn to 'the way the subject's own activity is inscribed into reality' (Žižek 2009:244 emphasis mine, see also Meylahn 2015).

What if God is not understood in transcendental terms at all, nor in radical transcendental terms as absolute unnameablilty, but is interpreted as a consequence of language, and therefore a part and parcel of language creating animals: humans? What if God is not understood as a human projection, as Feuerbach argued, but in terms of human language or grammatisation or technics ${ }^{18}$ or in Žižek's terms as 'the way the subject's own activity is inscribed into reality' (Žižek 2009:244). In other words, God is found in the grammatisation, the subject's own activity and how that activity (grammatisation) is inscribed onto reality, thus various inscriptions of playing with the unknowable and acknowledging that no conclusive final sacred story can be created, and yet acknowledging the possibility and mystery of the Other or Stranger, however weak and powerless the stranger may be (see also Meylahn 2015). This elusive Other is still emplotted into a form of sacred story. A story of, for example, offering welcome (hospitality) to the Other, loving the stranger and receiving through the stranger the gift of the postmetaphysical and post-onto-theological 'divine'. Thus, various postmetaphysical and post-onto-theological theologies (sacred stories) are developed, but yet no matter how weak (Caputo 2006) these theologies might be, or how much they seek to keep the challenges of both atheism and theism in conversation (Kearney 2010), they remain forms of a sacred story, or weak forms of conscious religion seeking to come to terms with what Van den Hoogen (2013) terms lived spirituality.

Postmetaphyiscal theologies are developed in an attempt to interpret lived spiritual experiences as consequences of some or other unknowable and unexplainable and elusive Otherness that breaks in, like a thief in the night, into the texts within contexts to disrupt them and opening them to the other. Terms that are used to express this relationship with

\footnotetext{
18.Bernard Stiegler $(2009,2010)$ argues for what Sylvain Arnoux called grammatisation (see Stiegler 2009:42). Grammatisation is the process by which 'both individual and groups individuate themselves (that is, become what they are) through and groups individuate themselves (that is, become what they are) through
expression, primarily through their utterances, but also through their gestures, expression, primarily through their utterances, but also through their gestures,
perceptions and transmissions of signs as well as their actions - which are also, perceptions and transmissions of signs as well as their actions - which are also,
secondarily an output of signs and information' (Stiegler 2009:42). The secondarily an output of signs and information' (Stiegler 2009:42). The
grammatisation process, according to Stiegler, already began in the Neolithic Age with the very first forms of notation, first the numerical systems and then ideograms (Stiegler 2009:43). Stiegler, following Bergson, Husserl and Barthes, describes this shift towards grammatisation as technics. He traces this development from the very early forms of notation to today's highly advanced development of industrial temporal objects (photography, recordings, radio, cinema, television YouTube) (Stiegler 2010:152). The movement from rural to urban in the early civilisations (see Stiegler 2009:43) began in the Neolithic Age with the earliest forms of (see Stiegler 2009 . forms of notation. What Stiegler is arguing is that without the development of grammatisation the development of the city and citizenship would not have been possible. These notations make the engramming of linguistic flux possible and thus forms the basis of the psychic and collective individuation processes that constitutes citizenship. 'The space and time of the cite, its geography and its history, or its geopolitics, are critical avant la lettre, in other words through the letter' (Stiegler 2009:43).
}

the Other are 'to offer welcome', 'hospitality', 'love' and 'gift' amongst others. There is another possibility for interpreting lived spirituality that does not necessarily end in a weak theology or anatheism. One can interpret these spiritual experiences not as the result of some or other elusive, unknowable Otherness that breaks in, but as the result of 'the way the subject's own activity is inscribed into reality' (Žižek 2009:244). It is the result of a flaw or lack in grammatisation, that is, because the text is not the Real, because of the Real's absolute foreclosure. Are these two possibilities opposites? Is one hereby not again creating a dualism, with two sides of the same coin, where one cannot think the one without thinking the other?

The position that I would like to take is that all one has is a text, which includes various texts (postmetaphysical theologies) concerning the Other (anatheism, weakness of God, God who may be, etc.). All these texts about Being, Other or Multiple are all different (philosophical, religious or even scientific texts). These texts become the material of thought, not their object (Other, Being or Multiple or Quantum, etc.), but the texts themselves become the material of non-philosophical thought.

All there is, is text, without access to either the Real or a super-real (metaphysical) Other, and yet the only way one can make sense of the text is with some or other notion of the Real or a metaphysical concept as it is believed that there is no escaping metaphysics. All these texts give an account of the Real via some or other philosophical decision (Laruelle 2013). There is no escaping a transcendent notion that gives credibility to the various texts concerning the Real. This transcendent notion is based on an arbitrary decision, that is, an arbitrary choice of transcendent notion whereby texts are believed to relate to the Real and/or Other or not to relate to the Real or Other.

The elusive Real can be seen in terms of a given-withoutgivenness ${ }^{19}$ and as a determination-in-the-last instant ${ }^{20}$ (see also Meylahn 2015). In other words, the various texts seek to understand, interpret and grasp (Begreifen) the Real and these attempts to understand, interpret and grasp are a result of the given-without-givenness of the real and therefore one can speak of determination-in-the-last-instance. The Real gives to thought, but without being given in thought and therefore a given-without-givenness, and yet that thought is determinedin-the-last instance by the given-without-givenness. The tree

\section{9.'We must add the first name of Given-without-givenness. By this we mean, then, the type of given that is radically given (to) itself rather than to a subject or to any other form of transcendence, and which is thus given without an operation of assumed givenness "behind" it, a background of the given. Instead of givenness determining the given under a quasi-objectifying mode, it is rather the given that determines the givenness, but in-the-last-instance only, and as such outside of any objectifying form'. (Laruelle, Francois (2013-05-09). Principles of Non-Philosophy (Kindle Locations 781-784). Bloomsbury Publishing. Kindle Edition).}

20.Thinking 'according-to-the-One. Radically immanent identity, or the Real, is the "form" of thought such that, refusing to turn itself toward the One as if toward a first or last object, it is necessarily turned toward philosophy and science. This impossibility of turning toward the One is not attributable to an insufficiency or forgetting of thought; it is rather a constraint that the One imposes upon thought, the grounding axiom of non-philosophy being that the One or the Real is foreclosed to thought and that this is of its own accord rather than owing to a failure of to thought and that this is of its own accord rather than owing to a failure of
thought' (Laruelle, Francois (2013-05-09). Principles of Non-Philosophy (Kindle Locations 355-359). Bloomsbury Publishing. Kindle Edition). 
that stands before me is given to thought and it comes to thought as an acacia tree, yet in the name 'acacia tree', the Real tree is not captured but is foreclosed, thus the name transports the real tree into the text (real-in-the-last-instant) via the name (text) and there the name serves as a dangerous supplement which is always also a pharmakon. Yet, the name, acacia tree, is determined-in-the-last-instance by the Real tree standing before me. A 'reality' is cloned of the Real tree on the basis of some or other transcendental theory of knowledge (epistemology), such as realism, idealism, scientism, romanticism, social constructionism, différance, etc. (see also Meylahn 2015). On the basis of that decision, reality is cloned as a vision-in-One.

This keeps one within the text, vision-in-One without an exit as the various transcendental decisions are not exits or links to the Other but theories based on arbitrary decisions and therefore different theories within the vision-in-One.

One cannot know the Real tree but only the cloned version thereof. This is what Derrida argues, that one cannot know the other or Other and therefore every other is wholly Other (tout autre est tout autre) (Derrida 1995:74). What Laruelle is probably arguing is that Derrida's différance is just one more philosophical decision linking or not linking text to the Real.

All there is, is text or all there is, is a clone: vision-in-One and it is all in-One.

\section{God in the text, God as infinite desertification of language}

Instead of seeking God beyond the text, the suggestion is to seek God in the text or rather as text: infinite desertification of language is Derrida's suggestion (Derrida 1995:55-56).

No conclusive statements can be made about God or about Reality, and therefore all statements about theism or atheism are speculations, just as statements about Reality are speculations. Derrida tries to avoid a new dualism between speculative realism and speculative mysticism concerning the Other or Stranger. The best way to avoid these different speculations is to focus on what one does have, namely texts, which one can understand as the turn to literature rather than the turn to religion (see also Meylahn 2015).

\section{Christ-poetics}

The way the subject's own activity is inscribed into reality could be stated as: the way the subject's grammatisation and thus individuation is inscribed: the given-without-givenness. The activity of the subject is the creation of signs to supplement reality and this supplemented or cloned reality becomes a dangerous supplement, according to Derrida, as it is always a pharmakon haunted by différance. Yet, Laruelle argues (2010) that différance is one more transcendental decision that relates texts (inscriptions) to Reality and therefore essentially remains a philosophy of difference. Derrida does not argue that différance marks the relationship between text and reality, but différance marks, scars, disrupts and auto-deconstructs texts. It is something grammatological, as something that happens in texts: autoimmunity. As something that happens in the body or text and yet he argues for the relationship between text and reality via his idea of the trace, which is closely linked to différance. The trace being a past that was never present and a future that is always still to come (see Derrida 1982:21; Meylahn 2015). This past never present and future always still to come haunts the texts, and this haunting characterises the relationship between texts and its Other. Laruelle argues, according to Brassier (2003:27), that this is still a non-relationship relationship. The alternative that Laruelle proposes is, I believe, a radicalisation of Derrida's premise that there is no outside text. Although he argues that reality is the determination-in-the-last-instance, it remains a given-without-givenness. The best way to maybe understand the text is as radical hyle, as axiomatic utterance, determined-in-the-last-instance, but still a given-withoutgivenness, as a cloned vision-in-One on the basis of one or other arbitrary decision (see Brassier 2001; Meylahn 2013a, 2015). A radical hyle 'enacts matter's transcendental foreclosure to thought within thought' (Brassier 2001:10).

Derrida's haunting of the text by otherness certainly opens the way for various forms of mysticism based on thinking, contemplating and offering hospitality to the elusive Spectre, Other or Strangers, and therefore it finds a lot of resonance in the various mystical turns in postmetaphysical theology. Following Laruelle, there is an alternative possibility of interpreting this relationship, without reference to the haunting of the text by the trace, namely by postulating an axiomatic heresy of the radical hyle. The idea of the radical hyle is very close to Derrida's dangerous supplement as pharmakon, yet without trying to understand the relationship between sign and reference. To understand the radical hyle as sign and therefore as dangerous supplement is based on the decision of différance and therefore Reality is cloned on the basis of that decision. Laruelle's non-philosophy is closer to science as it receives the given-without-givenness that is determined only in-the-last-instance, without trying to develop a philosophy or theory of the relationship based on some or other decision.

To understand the idea of the radical hyle (see also Meylahn 2015) or the given-without-givenness, yet determined-in-thelast-instance, one can turn to one of the earliest hymns, Carmen Christi, in the New Testament, Philippians 2:5-11. Here, one has an exposition of the Logos becoming flesh and making its dwelling amongst humanity in human culture and history (see Jn 1:14) as a determination-in-the-lastinstance. This incarnation, the becoming flesh, or being inscribed into human activity, or human history, or human culture, as human text did not seek equality with God. This inscription into human activity does not seek equality with the Other. It does not seek to be a true reflection of the Other but has emptied itself of all divine (Other) content. It is a given-without-givenness and yet it is believed to be the Son of God (axiomatic heresy), as it is believed to be determined-in- 
the-last-instance by the Other. There is no philosophy of difference that relates it to the Other, as it is empty of all divine content (see also Meylahn 2015). All there are, are dogmatic utterances that have to be believed (axiomatic heresies) about the relationship between Christ and the Father (Other). Christ enters the given-without-givenness as a radical hyle. His entrance into the text does not connect the given-without-givenness to the Real but saves the givenwithout-givenness from the infinite demand to be the final link to the Real and allows the given-without-givenness to embrace its determination-in-the-last instance, or its nakedness (see Meylahn 2010:8ff of 9). The Christ discourse as radical hyle allows the subject to embrace her/his symptom (see Meylahn 2010:8 of 9). It allows the text, human reason, to embrace that it is flawed and that communication always fails because of an inability and impossibility, as Lacan would say (see Verhaeghe 1995). Derrida argued that Lacan was too conclusive when he argued that the letter always arrives at its destination (Lacan 1972:53-55), when he argued that it perhaps arrives or does not arrive at its destination (Derrida 1975:44), as it is maybe haunted by the trace of the other. Laruelle would probably only partly agree with Derrida and argue that it is not haunted but determinedin-the-last-instance and radically turned or unifacially turned towards the future (Laruelle 2011:254) and thus the subjects are stranger subjects (Alkon \& Gunjevic 2011:219-220) - we are not citizens but aliens in the land (1 Pt 2:11). The stranger subject is closer to Saint Paul who knows nothing, but Christ and him crucified alone. Thus, it might be better to rather speak of a Christology where the logos has been crossed out or crucified as it cannot be developed into a theory to be understood like Lacan's discourse of the analyst. If it was a theory that can be understood, then it would also lead to work-righteousness. It is not a theory or philosophy of difference; it is not theism, atheism, panentheism or anatheism, but if anything, it is Christ and him crucified alone: sola Christus.

The stranger subject is also closer to the believer than Kearney's host welcoming the strangers in reference to Abraham at Mamre and Mary at the annunciation. Christ's incarnational association with the ones who are not, so as to bring to naught what is (1 Cor 1:27), cannot necessarily be understood as a welcoming (hospitality) offered to strangers and thereby a kind of mystical ethic of hospitality offered to strangers as Kearney develops. But, rather it is an openness to embrace the in-reason of language, rather than offering hospitality to that which is beyond language. As language is a host receiving the given-without-givenness and by virtue of some or other decision is cloning the given-without-givenness or the determination-in-the-last-instance into a vision of the Real as a unilateral duality. Language domesticates the given (guest) via decision to fit into the vision-in-One, but it cannot do otherwise. In Derrida's terms, language welcomes the trace (ghost) and materialises it. In the moment of materialisation, something is lost (pharmakon) or excluded, marginalised. Jesus' incarnation and ministry focussed on these exclusions. He focussed on those who are excluded by the law and those excluded by the ones who had the power to write the law and enforce the law. The power discourses that determined the materialisation, could thereby clearly identify who is included and who is excluded. Those excluded by not being acceptable, that is not acceptable according to the norm. Jesus associated with those who are excluded by this process of cloning based on some or other decision. He focussed on those marginalised by the dominant grammatisations, those who were not individuated into being acceptable citizens of either the Roman Empire or the chosen people of God. By association with those, Christ challenged the power discourses, he challenged the law, by challenging the decision and therefore language's ability of discretions. He challenged the possibility of forming citizens and therefore challenged the peace of the city as such. He challenged the Pax Romana and he challenged the Pharisees' and Sadducees' world of the chosen people. His challenge opened what is to what is not: an alternative and yet impossible city (or kingdom), a city (or kingdom) that is always still to come, where there are no discretions into Jew and Greek, man or woman, free or slave (Gl 3:28) (see also Meylahn 2015). By opting for the excluded, those who are not, to shame those who are, he transformed the city of citizens into a city of stranger subjects, unifacially turned towards the city that is always still to come in the time that remains.

Because he challenged the city, through his association with those who are not to put to shame, he was crucified by the powers that be, namely the guardians of the city, who are the guardians of the dominant grammatisations. His death on the cross is utter forsakenness - utter forsakenness of any justification, forsakenness of any way or ethic or ethos or decision: thus, Christology and therefore a Christ-poetics. The resurrection, after the third day, is the life that is possible after the crucifixion of the laws of individuation, the laws of grammatisation, a new impossible city to come where there is neither Jew or Greek, free or slave, man or woman.

\section{Acknowledgements Competing interests}

The author declares that he has no financial or personal relationships which may have inappropriately influenced him in writing this article.

\section{References}

Alkon, G. \& Gunjevic, B., 2011, 'According to the identity of the real: The non-philosophical thought of immanence', Synthesis Philosophica 51(1/2011) 209-227.

Brassier, R., 2001, 'Alien theory: The decline of materialism in the name of matter', PhD thesis, Department of Philosophy, University of Warwick.

Brassier, R., 2003, 'Axiomatic heresy: The non-philosophy of François Laruelle', Radical Philosophy 121, 24-35.

Caputo, J.D., 2006, The weakness of God: A theology of the event, Indiana University Press, Indianapolis, IN

Caputo, J.D., 2013, The Insistence of God: A theology of perhaps, Indiana University Press, Indianapolis, IN.

Crites, S., 1989, 'The narrative quality of experience', in S. Haerwas \& L.G. Jones (eds.), Why narrative? Readings in narrative theology, WM.B. Eerdmans, Grand Rapids, MI.

Derrida, J., 1975, 'The Purveyor of truth', in Graphesis: Perspectives in literature and philosophy, transl. W. Domingo, J. Hulbert \& M. Ron, Yale French Studies, No. 52, pp. 31-113, http://www.jstor.org/stable/2929747 
Derrida, J., 1981, Dissemination, transl. B. Johnson, Continuum, New York.

Derrida, J., 1982, Margins of philiosophy, transl. A. Bass, Harvester, Brighton.

Derrida, J., 1995, 'Sauf le nom', in J. Derrida \& T. Duoit (ed.), On the name, transl. D. Wood, J.J. Leavey \& I. McLeod, pp. 35-88, Stanford University Press, Stanford, CA.

Derrida, J., 1997, Of grammatology, transl. G.C. Spivak, John Hopkins Press, Baltimore, MD.

Derrida, J., 2003, 'The "World" of the enlightenment to comes (exception, calculation, sovereignty)', in Research in phenomenology, vol. 33, pp. 9-52, Koninklijke Brill NV, Leiden.

Derrida, J., 2005, Politics of friendship, transl. G. Collins, Verso, New York.

Derrida, J., 2008, 'How to avoid speaking: Denials', in P. Kamuf \& E. Rottenberg (eds.) Psyche: Inventions of the other, vol. II, transl. K. Frieden \& E. Rottenberg, pp. 143-195, Stanford University Press, Stanford, CA.

Heidegger, M., 2003, 'Overcoming metaphysics', in Martin Heidegger: The end of philosophy, transl. J. Stambaugh, pp. 84-110, University of Chicago, Chicago, IL.

Horner, R., 2001, Rethinking God as gift: Marion, Derrida, and the limits of phenomenology, Fordham University Press, New York.

Kearney, R., 2001, The God who may be: A hermeneutics of religion, Indiana University Press, Bloomington, $\mathrm{CA}$.

Kearney, R., 2010, Anatheism: Returning to God after God, Kindle edition, Columbia University Press E-book, New York.

Lacan, J., 1972, 'Seminar on "The Purloined Letter"', in French Freud: Structural studies in psychoanalysis, transl. J. Mehlman, Yale French Studies, No. 48, pp. 39-72.

Laruelle, F., 2010, Philosophies of difference: A critical introduction to non-philosophy, transl. R. Gangle, Kindle edition, Continuum, New York.

Laruelle, F., 2011, 'The generic as predicate and constant: Non-philosophy and materialism', in L. Bryant, N. Srnicek \& G. Harman (eds.), The speculative turn: materialism', in L. Bryant, N. Srnicek \& G. Harman (eds.), The speculative
Continental materialism and realism, pp. 237-260, re.press, Melbourne.

Laruelle, F., 2013, Principles of non-philosophy, transl. N. Rubszak \& A.P. Smith, Kindle edition, Bloomsbury, London.

Laruelle, F., 2014, 'Deconstruction and non-philosophy', in Chiasma: A Site For Thought Vol. 1, Issue 1: What the Doing of Thinking Does and Doesn't Do Today, transl. N. Hauck, pp. 54-63.
Levinas, E., 1969, Totality and infinity: An essay on exteriority, transl. A. Lingis, Duquesne University Press, Pittsburgh, PA.

Meylahn, J.A., 2010, 'Holistic redemptive pastoral ministry in the fragmented transit hall of existence', HTS Teologiese Studies/Theological Studies 66(1), Art. \#426, 1-9. http://dx.doi.org/10.4102/hts.v66i1.426

Meylahn, J.A., 2013a, 'The hidden potential of pre-theoretical transversal events or advents of a Rainbow Nation', HTS Teologiese Studies/Theological Studies 69(1). http://dx.doi.org/10.4102/hts.v69i1.1305

Meylahn, J.A., 2013b, The limits and possibilities of postmetaphysical God-talk: A conversation between Heidegger, Levinas and Derrida, Studies in Philosophical Theology 52, Peeters, Leuven.

Meylahn, J.A., 2015, 'Doing public theology in the anthropocene towards life-creating theology', Verbum et Ecclesia 36(3), Art. \#1443, 1-10. http://dx.doi.org/10.4102/ ve.v36i3.1443

Nancy, J.-L., 2008, Dis-enclosure: The deconstruction of Christianity, transl. B. Bergo, G. Malenfant \& M. B. Smith, Fordham University Press, New York.

Ricoeur, P., 1984, Time and narrative, vol.1, transl. K. McLaughlin \& D. Pellauer, University of Chicago Press, Chicago, IL.

Schrag, C.O., 2002, God as otherwise than Being: Toward a semantics of the gift, Northwestern University Press, Evanston, IL.

Stiegler, B., 2009, 'The carnival of the new screen: From hegemony to Isonomy, The YouTube reader', in P. Snickars \& P. Vonderau (eds.), Stockholm, Medienhistoriskt Arkiv 12., pp. 40-59.

Stiegler, B., 2010, 'Technics of decision an interview', Angelaki: Journal of the Theoretical Humanities 8(2), 151-168. http://dx.doi.org/10.1080/096972503200 0162639

Van den Hoogen, T., 2013, Academic table discussion at the university of Pretoria, 06.06.2013, Spirituality of Foundational theology by Prof. dr. Toine van den Hoogen of the Theology Faculty of Njmegen, The Netherlands.

Verhaeghe, P., 1995, 'From impossibility to inability: Lacan's theory on the four discourses', The Letter: Lacanian Perspectives on Psychoanalysis 3(Spring), 91-108.

Žižek, S., 2009, 'Dialectical Clarity versus the Misty Conceit of Paradox', in C. Davis (ed.), The monstrosity of Christ: Paradox or dialectic?, The MIT Press, Cambridge, MA. 